\title{
Differential modulation by vanadium pentoxide of the secretion of CXCL8 and CXCL11 chemokines in thyroid cells
}

\author{
POUPAK FALLAHI $^{1}$, RUDY FODDIS ${ }^{2}$, GIUSY ELIA ${ }^{1}$, FRANCESCA RAGUSA $^{1}$, \\ ARMANDO PATRIZIO $^{1}$, GIADA FRENZILLI ${ }^{1}$, SALVATORE BENVENGA $^{3-5}$, \\ ALFONSO CRISTAUDO $^{2}$, ALESSANDRO ANTONELLI ${ }^{1}$ and SILVIA MARTINA FERRARI ${ }^{1}$

\begin{abstract}
Departments of ${ }^{1}$ Clinical and Experimental Medicine, and ${ }^{2}$ Translational Research of New Technologies in Medicine and Surgery, University of Pisa, I-56126 Pisa; ${ }^{3}$ Department of Clinical and Experimental Medicine,

Section of Endocrinology; ${ }^{4}$ Master Program on Childhood, Adolescent and Women's Endocrine Health,

University of Messina; ${ }^{5}$ Interdepartmental Program on Molecular and Clinical Endocrinology, and Women's Endocrine Health, Azienda Ospedaliera Universitaria Policlinico ‘G. Martino’, I-98125 Messina, Italy
\end{abstract}

Received November 1, 2017; Accepted March 6, 2018

DOI: $10.3892 / \mathrm{mmr} .2018 .8764$

\begin{abstract}
Recently it has been hypothesized that vanadium serves a carcinogenic role in the thyroid. However, to date, no in vivo or in vitro studies have evaluated thyroid disruption in humans and/or animals following exposure to vanadium. The present study evaluated the effect of vanadium pentoxide $\left(\mathrm{V}_{2} \mathrm{O}_{5}\right)$ on cell viability and proliferation, and chemokine (C-X-C motif) ligand (CXCL) 8 and CXCL11 secretion in normal thyrocytes. The results demonstrated that $\mathrm{V}_{2} \mathrm{O}_{5}$ had no effect on thyroid follicular cell viability and proliferation. However, $\mathrm{V}_{2} \mathrm{O}_{5}$ was able to induce the secretion of CXCL8 and CXCL11 chemokines from thyrocytes. Notably, $\mathrm{V}_{2} \mathrm{O}_{5}$ synergistically increased the effect of the interferon (IFN)- $\gamma$ on CXCL11 secretion. In addition, $\mathrm{V}_{2} \mathrm{O}_{5}$ synergistically increased the effect of tumor necrosis factor- $\alpha$ on CXCL8 secretion, and abolished the inhibitory effect of IFN $-\gamma$. Overall this induction of CXCL8 and CXCL11 secretion may lead to the induction and perpetuation of an inflammatory reaction in the thyroid. Further studies are now required to evaluate thyroid function and nodule development in subjects who are occupationally exposed, or living in polluted areas.
\end{abstract}

\section{Introduction}

Vanadium pentoxide $\left(\mathrm{V}_{2} \mathrm{O}_{5}\right)$ is the most common form of vanadium, a grey metal existing in different states of oxidation

Correspondence to: Professor Alessandro Antonelli, Department of Clinical and Experimental Medicine, University of Pisa, Via Savi 10, I-56126 Pisa, Italy

E-mail: alessandro.antonelli@med.unipi.it

Key words: vanadium, chemokine (C-X-C motif) ligands 8 and 11, chemokines, thyroid cells, environmental exposure, occupational exposure
$(-1,0,+2,+3,+4$, and +5$)$. The majority of vanadium compounds are considered to be toxic.

The Occupational Safety and Health Administration (OSHA) fixed a workplace threshold for $\mathrm{V}_{2} \mathrm{O}_{5}$ in the air of $0.05 \mathrm{mg} / \mathrm{m}^{3}$ for the dust and $0.1 \mathrm{mg} / \mathrm{m}^{3}$ for fumes (when considering an $8 \mathrm{~h}$ workday/40 h work week) (1). Exposure to a $35 \mathrm{mg} / \mathrm{m}^{3}$ dose of vanadium it is considered dangerous and may provoke serious and perpetual health issues that can lead up to death [as established by The National Institute for Occupational Safety and Health (NIOSH)] (1). The toxic effects of vanadium mainly impact the respiratory system; effects on the gastrointestinal system are less relevant due to the minimal gut absorption rate of the substance (2-4). However, due to insufficient data, it is not possible to determine the reference range of a subchronic or chronic inhaled dose at present.

Previous studies have evaluated the effects of oral or inhaled vanadium exposures on serum parameters $(5,6)$, on liver (7), and nervous system (8), and other tissues (9), in rat models.

It has been recently suggested that volcanic pollution exerts a carcinogenic effect. Indeed, the incidence of thyroid cancer registered in the Mount Etna volcanic area was found to be higher with respect to a control area (18.5 and 9.6/105 inhabitants, respectively). Many trace elements are increased in volcanic areas compared with control areas, in both drinking water and lichens, indicating both water and atmospheric pollution; among all the increased elements, vanadium was 8 times higher, suggesting that it is a major determinant in the carcinogenic effect of volcanic pollution on the thyroid $(10,11)$. To date, however, no in vivo or in vitro studies have evaluated thyroid/endocrine disruption in humans and/or animals following vanadium exposure.

Recently, it has been investigated whether the secretion of chemokine (C-X-C motif) ligand (CXCL) 8 and CXCL10 by normal human thyrocytes is dependent upon specific proinflammatory stimuli. The secretion of CXCL8 but not of CXCL10 has been detected under basal conditions from thyrocytes. Furthermore, the two chemokines show differences 
in their response to proinflammatory cytokines. Indeed, significant secretion of CXCL10 was induced by interferon (IFN)-gamma and not by tumor necrosis factor (TNF)-alpha, whereas CXCL8 was secreted in response to TNF-alpha, while being inhibited by IFN-gamma; meanwhile, a combination of TNF-alpha plus IFN-gamma synergistically increased the IFN-gamma-induced CXCL10 secretion, while reducing the TNF-alpha-induced CXCL8 secretion (12).

Moreover, it has been recently shown that CXCL10 mRNA and protein levels were increased by $\mathrm{V}_{2} \mathrm{O}_{5}(13)$, and $\mathrm{V}_{2} \mathrm{O}_{5}$ exposure is a cause of occupational bronchitis, as a study evaluated gene expression profiles in human lung fibroblasts (in cultures) after $\mathrm{V}_{2} \mathrm{O}_{5}$ exposure, showing that among the 10 genes overexpressed by $\mathrm{V}_{2} \mathrm{O}_{5}$, also $C X C L 8, C X C L 9$ and $C X C L 10$ were induced (14).

For these reasons, we evaluate the effect of $\mathrm{V}_{2} \mathrm{O}_{5}$ on the secretion of CXCL8 and CXCL11 chemokines from normal thyrocytes.

\section{Materials and methods}

Thyroid follicular cells. We obtained samples of thyroid tissue from 10 euthyroid patients ( 5 females and 5 males, mean age, 41 years; age range, 24-61), of whom 8 had undergone prior parathyroidectomy, and 2 had undergone laryngeal intervention. Written informed consent for the study was obtained from all patients, and the study was approved by the local Ethical Committee of the University of Pisa (Pisa, Italy).

Thyrocytes were prepared from the tissue samples, as reported previously (15-17). In brief, the tissue samples were digested with collagenase (Roche, Mannheim, Germany; $1 \mathrm{mg} / \mathrm{ml}$ ) with RPMI 1640 medium (Whittaker Bioproducts, Inc., Walkersville, MD, USA) for $1 \mathrm{~h}$ at temperature of $37^{\circ} \mathrm{C}$. Subsequently, semi-digested follicles were removed and sedimented for $2 \mathrm{~min}$; they were then washed and cultured with RPMI 1640 containing 10\% fetal bovine serum (FBS) (Seromed, Berlin, Germany), $50 \mathrm{mg} / \mathrm{ml}$ penicillin/streptomycin and $2 \mathrm{mM}$ glutamine with $5 \% \mathrm{CO}_{2}$ at $37^{\circ} \mathrm{C}$. The cells were all used at the 4th passage.

Cell viability and proliferation assay. We assessed cell viability and proliferation with a WST-1 assay (Roche Diagnostics, Almere, The Netherlands), which is based on the use of 3-[4,5-dimethylthiazol-2-yl]-2,5-diphenyltetrazolium bromide of the MTT assay (17-19). We seeded thyroid follicular cells (TFC) in each well of a 96-well plate at a concentration of 35,000 cells $/ \mathrm{ml}$ in a final volume of $100 \mu \mathrm{l}$. To evaluate the effects of $\mathrm{V}_{2} \mathrm{O}_{5}$ on TFC viability and proliferation, we treated the TFC for $24 \mathrm{~h}$ with increasing concentrations of $\mathrm{V}_{2} \mathrm{O}_{5}$ $(1,10$ and $100 \mathrm{nM})$. The experiments were performed in triplicate for each cell preparation. The plated cells were treated for $24 \mathrm{~h}$ with $\mathrm{V}_{2} \mathrm{O}_{5}$ or its vehicle alone.

Proliferation assay: Cell counting. As the cell viability and proliferation WST-1 assay may have limitations on evaluating cellular proliferation (20), we also performed cell number counting to evaluate the proliferation of the TFCs [see above $(18,19,21-23)]$. In the cell counting method, cells were seeded at a density of 13,000 cells per well in 24 -well tissue culture plates in a medium supplemented with $10 \%$ v/v FBS, with increasing concentrations of $\mathrm{V}_{2} \mathrm{O}_{5}(1,10$ and $100 \mathrm{nM}$ ). After $24 \mathrm{~h}$ in an atmosphere of $5 \% \mathrm{CO}_{2}$ and $95 \%$ air at $37^{\circ} \mathrm{C}$, the cells were detached from the plates by incubation with $500 \mathrm{ml}$ phosphate-buffered saline (PBS) containing $100 \mathrm{mg}$ trypsin and $1 \mathrm{mmol} / \mathrm{l}$ ethylenediaminetetraacetic acid (EDTA). The cells were then counted using a haemocytometer $(18,19,21-23)$.

Chemokine secretion assay and ELISA. To analyse CXCL8,

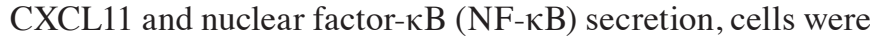
seeded in 96-well plates at a concentration of 30,000 cells $/ \mathrm{ml}$ in a final volume of $100 \mu \mathrm{l} /$ well in growth medium, which was removed after $24 \mathrm{~h}$. The seeded cells were washed in PBS, then incubated, for $24 \mathrm{~h}$ in phenol red and serum-free medium with IFN-gamma (R\&D Systems, Minneapolis, MN, USA; 500; 1,$000 ; 5,000$ and 10,000 IU/ml), and $10 \mathrm{ng} / \mathrm{ml}$ TNF-alpha (R\&D Systems), alone or in combination (16). We performed preliminary experiments to select the TNF-alpha concentration, in order to achieve maximal responses (data not shown).

To evaluate how $\mathrm{V}_{2} \mathrm{O}_{5}$ may affect chemokine secretion induced by IFN-gamma, we exposed the cells for $24 \mathrm{~h}$ to increasing concentrations of $\mathrm{V}_{2} \mathrm{O}_{5}(1,10$ and $100 \mathrm{nM})$ in the presence or absence of IFN-gamma (1,000 IU/ml), and/or TNF-alpha (10 ng/ml).

An ELISA assay was used to evaluate CXCL8, CXCL11 and nuclear factor- $\mathrm{\kappa B}(\mathrm{NF}-\mathrm{\kappa B})$ concentrations in the supernatants. The experiments were carried out three times with each different cell preparation.

CXCL11 and CXCL8 levels were measured in the culture supernatants with commercially available kits (R\&D Systems). The mean minimum detectable dose was $2.9 \mathrm{pg} / \mathrm{ml}$ for CXCL8 and $3.4 \mathrm{pg} / \mathrm{ml}$ for CXCL11; the intra- and inter-assay coefficients of variation were 3.4 and $6.2 \%$ for CXCL8, and 4.9 and $8.3 \%$ for CXCL11. NF- $\kappa B$ levels were measured in the culture supernatants by ELISA (Antibodies online; product no. ABIN 414848). The mean minimum detectable dose was $0.15 \mathrm{ng} / \mathrm{ml}$ (detection range, $0.15-10 \mathrm{ng} / \mathrm{ml}$ ).

Quality control pools of low, normal, and high concentration for all parameters were included in each assay.

Statistical analysis. Values are presented as the mean \pm standard deviation for normally distributed variables (in text), or as the mean \pm standard error mean (in figures), or as the medians and interquartile range. Mean group values were compared using one-way analysis of variance for normally distributed variables, or the Mann-Whitney U or Kruskal-Wallis test was performed. Proportions were compared with the Chi-Square test. For multiple comparisons, the post-hoc Bonferroni-Dunn test was applied for comparisons on normally distributed variables.

\section{Results}

Cell viability and proliferation. Cell counting showed that $\mathrm{V}_{2} \mathrm{O}_{5}(1,10$ or $100 \mathrm{nM})$ did not change the viability or proliferation rate of TFCs (Fig. 1). These results were confirmed by the WST-1 assay (data not shown). Meanwhile, when treating TFC cells with $\mathrm{V}_{2} \mathrm{O}_{5}$ at 250 and $500 \mathrm{nM}$, viability and proliferation was inhibited by 17 and 28\%, respectively (Fig. 1). 


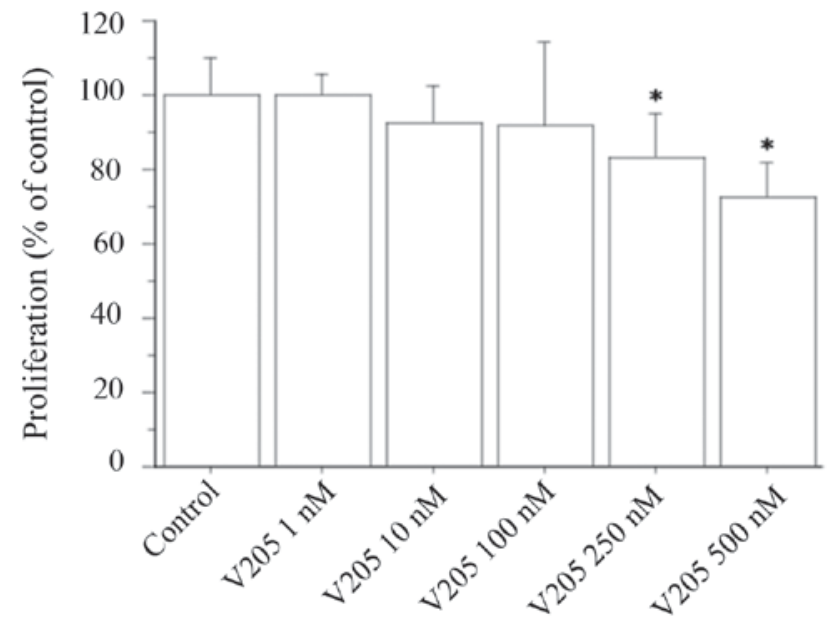

Figure 1. Cell viability and proliferation. Cell counting analysis revealed that $\mathrm{V}_{2} \mathrm{O}_{5}(1,10$ and $100 \mathrm{nM})$ did not change the viability and proliferation rate of thyroid follicular cells, while 250 and $500 \mathrm{nM}$ reduced it by 17 and $28 \%$, respectively. ${ }^{*} \mathrm{P} \leq 0.05$ vs. control. $\mathrm{V}_{2} \mathrm{O}_{5}$, vanadium pentoxide.

CXCL8 secretion from TFC cells. CXCL8 secretion was measured for all cultured thyroid cell preparations, and under basal conditions, ranged from 37.8 to $173.5 \mathrm{pg} / \mathrm{ml}$ (Fig. 2A). This secretion increased dose-dependently with increasing concentrations of TNF-alpha $(1,5$ and $10 \mathrm{ng} / \mathrm{ml})$, with the highest response obtained with $10 \mathrm{ng} / \mathrm{ml}$ TNF-alpha (basal 94 \pm 32 pg/ml vs. TNF-alpha $931 \pm 257 \mathrm{pg} / \mathrm{ml} ; \mathrm{P}<0.01$ ) (Fig. 2A).

By contrast, IFN-gamma (1,000 IU/ml) significantly inhibited the basal CXCL8 secretion (IFN-gamma $28 \pm 16 \mathrm{pg} / \mathrm{ml}$ vs. basal; $\mathrm{P}<0.05$ ) (Fig. 2B). Furthermore, the stimulatory effect of TNF-alpha was significantly reversed after the addition of IFN-gamma (TNF-alpha+IFN-gamma $412 \pm 141 \mathrm{pg} / \mathrm{ml}$ vs. TNF-alpha 931 $\pm 257 \mathrm{pg} / \mathrm{ml}$; $\mathrm{P}<0.05$ ) (Fig. 2B). However, IFN-gamma did not completely reverse the stimulatory effect of TNF-alpha on the secretion of CXCL8, as CXCL8 concentration remained significantly higher with respect to the basal conditions (TNF-alpha+IFN-gamma vs. basal; $\mathrm{P}<0.01)$.

CXCL8 release was also dose-dependently stimulated from thyrocytes following treatment with $\mathrm{V}_{2} \mathrm{O}_{5}(1,10$ and $100 \mathrm{nM})$ (ANOVA, P<0.0001) (Fig. 3A). When treating thyrocytes with $\mathrm{V}_{2} \mathrm{O}_{5}(100 \mathrm{nM})$ together with IFN-gamma, CXCL8 release was not significantly changed with respect to the basal level, and the inhibitory effect of IFN-gamma was not observed; however the stimulatory effect of $\mathrm{V}_{2} \mathrm{O}_{5}$ was abolished (Fig. 3B).

CXCL8 release was synergistically increased (ANOVA, $\mathrm{P}<0.0001)$ when cells were treated with $\mathrm{V}_{2} \mathrm{O}_{5}(100 \mathrm{nM})$ together with TNF-alpha, compared to TNF-alpha alone (Fig. 3C). Additionally, when treating thyrocytes with $\mathrm{V}_{2} \mathrm{O}_{5}$ (100 nM), plus IFN-gamma and TNF-alpha, CXCL8 release was synergistically increased (ANOVA, $\mathrm{P}<0.0001$ ), and the inhibitory effect of IFN-gamma was abolished (Fig. 3D).

CXCL11 secretion from TFC cells. CXCL11 was not detectable in the supernatants obtained from primary thyrocyte cultures. IFN-gamma dose-dependently induced CXCL11 release (CXCL11 level: 0, 26 $\pm 13,65 \pm 25,102 \pm 32,145 \pm 48 \mathrm{pg} / \mathrm{ml}$; respectively, with IFN-gamma at $0 ; 500 ; 1,000 ; 5,000$ and 10,000 IU/ml; ANOVA, P<0.001), whereas TNF-alpha alone
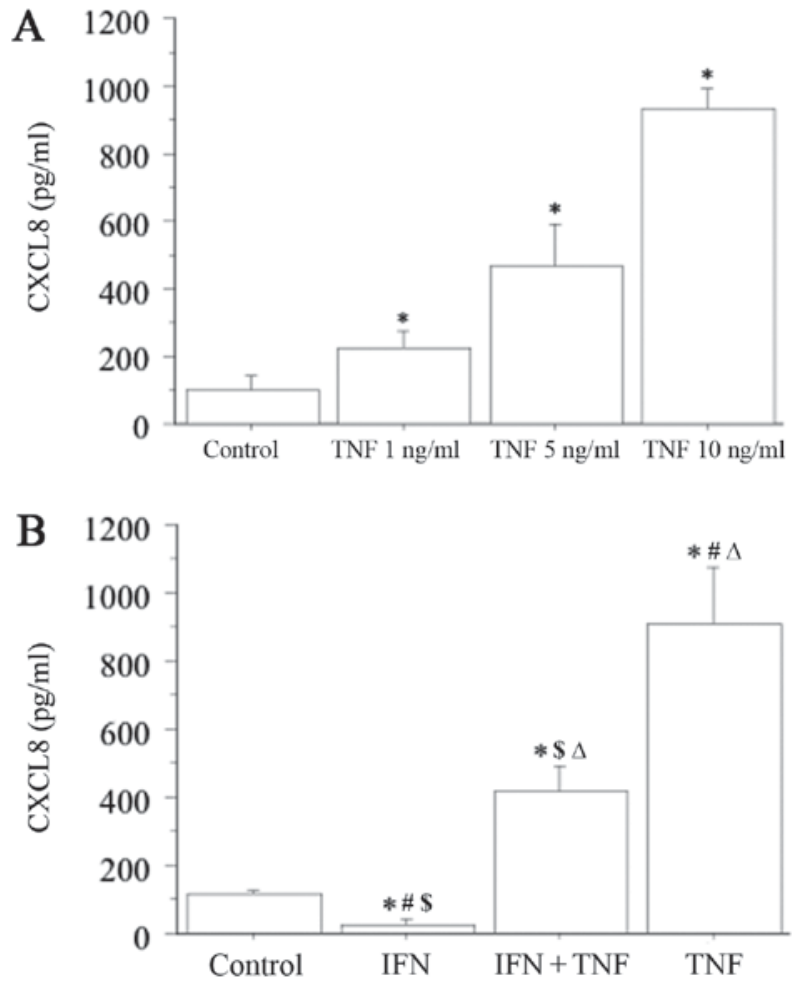

Figure 2. CXCL8 secretion from thyroid follicular cells following TNF- $\alpha$ and/or IFN- $\gamma$ treatment. (A) CXCL8 secretion was measured in all cultured thyroid cell preparations in basal conditions (Control). CXCL8 secretion increased dose-dependently with increasing concentrations of TNF- $\alpha(1,5$ and $10 \mathrm{ng} / \mathrm{ml}$ ), with the highest response obtained with $10 \mathrm{ng} / \mathrm{ml} \mathrm{TNF}-\alpha$. (B) IFN- $\gamma(1,000 \mathrm{IU} / \mathrm{ml})$ significantly inhibited basal CXCL8 secretion. The stimulatory effect of TNF- $\alpha$ was significantly reversed following the addition of IFN- $\gamma$. IFN- $\gamma$ did not completely reverse the stimulatory effect of TNF- $\alpha$ on the secretion of CXCL8, as the CXCL8 concentration remained significantly higher with respect to basal conditions. ${ }^{*} \mathrm{P}<0.05$ vs. control; ${ }^{\#} \mathrm{P}<0.05$ vs. IFN+TNF; ${ }^{\mathrm{P}}<0.05$ vs. TNF; ${ }^{\Delta} \mathrm{P}<0.05$ vs. IFN. CXCL8, chemokine (C-X-C motif) ligand 8 ; TNF, tumor necrosis factor; IFN, interferon.

had no effect (CXCL11 remained undetectable). The combination of IFN-gamma and TNF-alpha had a significant synergistic effect on CXCL11 secretion (CXCL11 level, 1,354 \pm 132 vs. $65 \pm 25 \mathrm{pg} / \mathrm{ml}$ with IFN-gamma alone, ANOVA, $\mathrm{P}<0.0001)$.

CXCL11 release was dose-dependently stimulated from thyrocytes following treatment with $\mathrm{V}_{2} \mathrm{O}_{5}(1,10$ and $100 \mathrm{nM})$ (ANOVA, $\mathrm{P}<0.0001$ ) (Fig. 4A). This CXCL11 release was not significantly changed on treatment of the cells with $\mathrm{V}_{2} \mathrm{O}_{5}$ (100 nM) together with TNF-alpha compared with $\mathrm{V}_{2} \mathrm{O}_{5}$ treatment alone (data not shown). Meanwhile, $\mathrm{V}_{2} \mathrm{O}_{5}(100 \mathrm{nM})$ together with IFN-gamma synergistically increased CXCL11 release (ANOVA, P<0.0001) (Fig. 4B). CXCL11 release was also synergistically increased (ANOVA, $\mathrm{P}<0.0001$ ) when thyrocytes were treated with $\mathrm{V}_{2} \mathrm{O}_{5}(100 \mathrm{nM})$ together with IFN-gamma and TNF-alpha (Fig. 4C).

$N F-\kappa B$ secretion from $T F C$ cells. NF- $\kappa \mathrm{B}$ levels were measured in the supernatants obtained from primary thyrocyte cultures. $\mathrm{NF}-\kappa \mathrm{B}$ release was dose-dependently stimulated by treating thyrocytes with $\mathrm{V}_{2} \mathrm{O}_{5}(1,10$ and $100 \mathrm{nM})$, with respect to control treatment (ANOVA, $\mathrm{P}<0.005$ ). NF- $\kappa \mathrm{B}$ was increased by $4 \%$ vs. the control with $1 \mathrm{nM} \mathrm{V}_{2} \mathrm{O}_{5}$; by $16 \%$ vs. the control with $10 \mathrm{nM} \mathrm{V}_{2} \mathrm{O}_{5}$; and by $31 \%$ vs. the control with $100 \mathrm{nM}$ $\mathrm{V}_{2} \mathrm{O}_{5}$ (Fig. 5). 

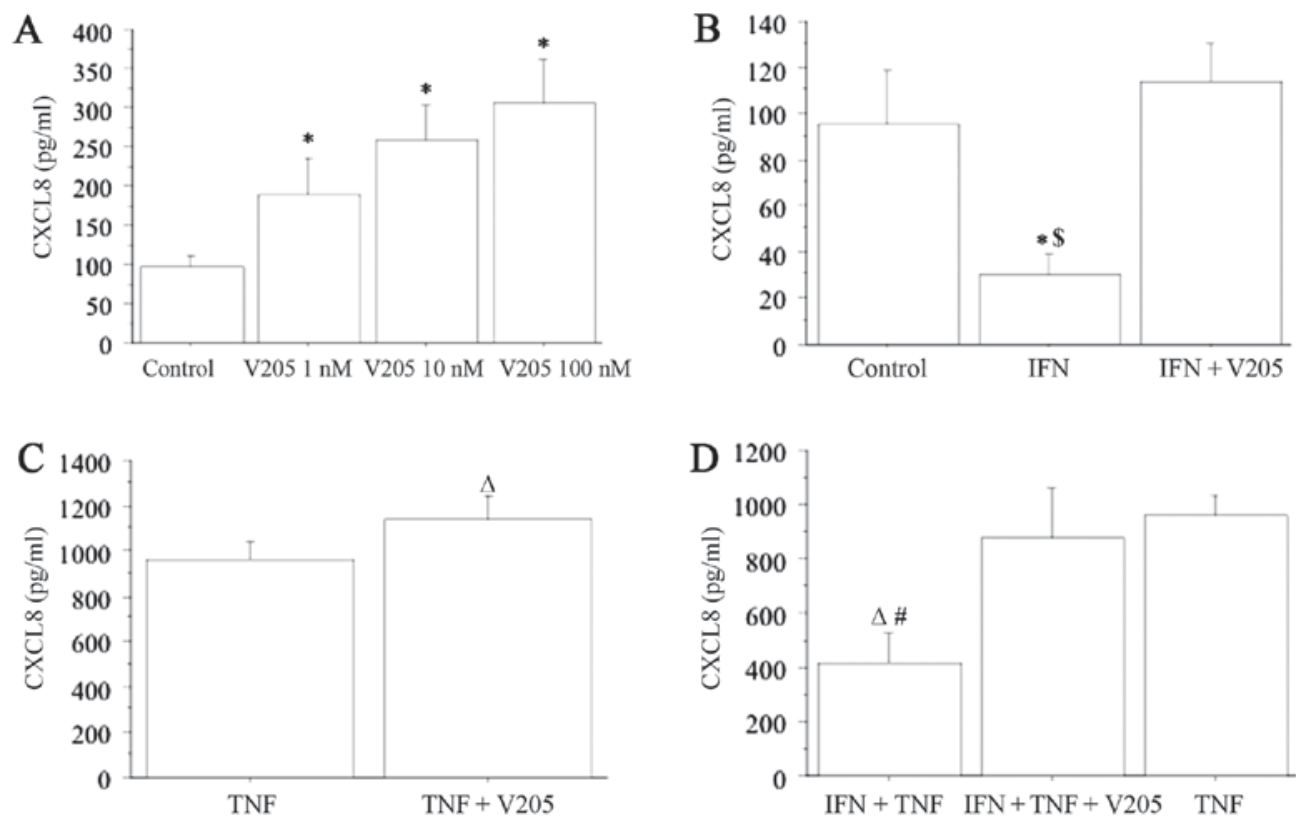

Figure 3. CXCL8 secretion from thyroid follicular cells following $\mathrm{V}_{2} \mathrm{O}_{5}$ and/or TNF- $\alpha$ and/or IFN- $\gamma$ treatment. (A) CXCL8 release was dose-dependently stimulated by the treatment of thyrocytes with $\mathrm{V}_{2} \mathrm{O}_{5}(1,10$ and $100 \mathrm{nM})$. (B) Following treatment with $\mathrm{V}_{2} \mathrm{O}_{5}(100 \mathrm{nM})$ together with IFN- $\gamma$, CXCL8 release was not significantly altered with respect to basal conditions, and the inhibitory effect of IFN- $\gamma$ was not observed; however the $\mathrm{V}_{2} \mathrm{O}_{5}$ stimulatory effect was abolished. (C) CXCL8 release was synergistically increased when cells were treated with $\mathrm{V}_{2} \mathrm{O}_{5}(100 \mathrm{nM})$ together with TNF- $\alpha$. (D) Following treatment with $\mathrm{V}_{2} \mathrm{O}_{5}(100 \mathrm{nM})$ plus IFN- $\gamma$ and TNF- $\alpha$ stimulation, CXCL8 release was synergistically increased, abolishing the inhibitory effect of IFN- $\gamma$. ${ }^{*} \mathrm{P}<0.05 \mathrm{vs}$. control; ${ }^{\$} \mathrm{P}<0.05$ vs. IFN $+\mathrm{V}_{2} \mathrm{O}_{5} ;{ }^{\#} \mathrm{P}<0.05$ vs. IFN+TNF+ $\mathrm{V}_{2} \mathrm{O}_{5} ;{ }^{\mathrm{A}} \mathrm{P}<0.05$ vs. TNF. CXCL8, chemokine (C-X-C motif) ligand 8; TNF, tumor necrosis factor; $\mathrm{V}_{2} \mathrm{O}_{5}$, vanadium pentoxide; IFN, interferon.

\section{Discussion}

Our results show that $\mathrm{V}_{2} \mathrm{O}_{5}$ can promote the secretion of CXCL8 and IFN-gamma dependent CXCL11 secretion from TFCs, without altering the viability and proliferation of the cells. Moreover, our study confirmed that IFN-gamma and TNF-alpha stimulated CXCL11 secretion as expected (17). Interestingly, CXCL11 secretion was increased by $\mathrm{V}_{2} \mathrm{O}_{5}$ combined with IFN-gamma and TNF-alpha. Furthermore, a synergistic influence on CXCL8 secretion was elicited by $\mathrm{V}_{2} \mathrm{O}_{5}$ combined with TNF-alpha, which abolished the inhibitory effect of IFN-gamma. Our results, on the whole, suggest that $\mathrm{V}_{2} \mathrm{O}_{5}$ can induce and perpetuate an inflammatory disorder in the thyroid by inducing the secretion of inflammatory chemokines (18).

CXCL8, also called neutrophil chemotactic factor, has two primary functions: it induces chemotaxis in target cells, especially neutrophils but also other granulocytes, causing them to migrate toward the site of infection; it is a potent promoter of angiogenesis and it is often associated with inflammation.

Whether the secretion of CXCL8 and CXCL10 by normal human thyrocytes depends on specific proinflammatory stimuli has been recently investigated. CXCL8 but not CXCL10 was detected in basal conditions. The two chemokines showed differences in their response to proinflammatory cytokines, as a significant secretion of CXCL10 was induced by IFN-gamma and not TNF-alpha, while CXCL8 was secreted in response to TNF-alpha and inhibited by IFN-gamma. The combination of TNF-alpha and IFN-gamma synergistically increased the IFN-gamma-induced CXCL10 secretion, and reversed the TNF-alpha-induced CXCL8 secretion (12).

It has recently been suggested that CXCL8 sustains a first step toward a differentiation between autoimmune and tumor-related inflammation in the thyroid (12). Therefore, it is feasible that the induction of CXCL8 secretion from thyrocytes by $\mathrm{V}_{2} \mathrm{O}_{5}$ could sustain a tumor-related inflammatory response in the thyroid.

CXCL11 binds to the same chemokine receptor CXCR3 as CXCL10 but with higher affinity and potency; its expression is strongly increased in response to IFN-gamma and is involved in the recruitment of T-helper 1 (Th1) lymphocytes to sites of inflammation.

Furthermore, several types of normal mammalian cells (such as thyrocytes, fibroblasts, colon epithelial cells, islet cells and others) $(15-19,21,24,25)$ can produce IFN-gamma-inducible $\mathrm{C}-\mathrm{X}-\mathrm{C}$ chemokines. However, these cells are not able to produce the $\mathrm{C}-\mathrm{X}-\mathrm{C}$ chemokines under basal conditions, but only after stimulation by cytokines such as IFN-gamma and TNF-alpha, which are generally secreted in a Th1 type inflammatory sites, such as the thyroid at the beginning of Graves' disease, by Th1-activated lymphocytes. This process has been suggested to be involved in the initiation and the perpetuation of the inflammation in several autoimmune diseases (15-19,21,24-27), and on the basis of our results may be applicable to the thyroid.

Moreover, our results showed a dose-dependent increase in $\mathrm{NF}-\kappa \mathrm{B}$ release following the treatment of thyrocytes with $\mathrm{V}_{2} \mathrm{O}_{5}$ with respect to control treatment. NF- $\kappa \mathrm{B}$ is a transcription factor found in almost all animal cell types, that is involved in cellular responses to stimuli (such as bacterial or viral antigens, stress, cytokines, heavy metals, free radicals, ultraviolet irradiation, and others) and has a determinant role in regulating the immune response. Its increase in our study suggests that vanadium may act on the $N F-\kappa B$ pathway to induce a final effect on chemokines, which is in agreement 

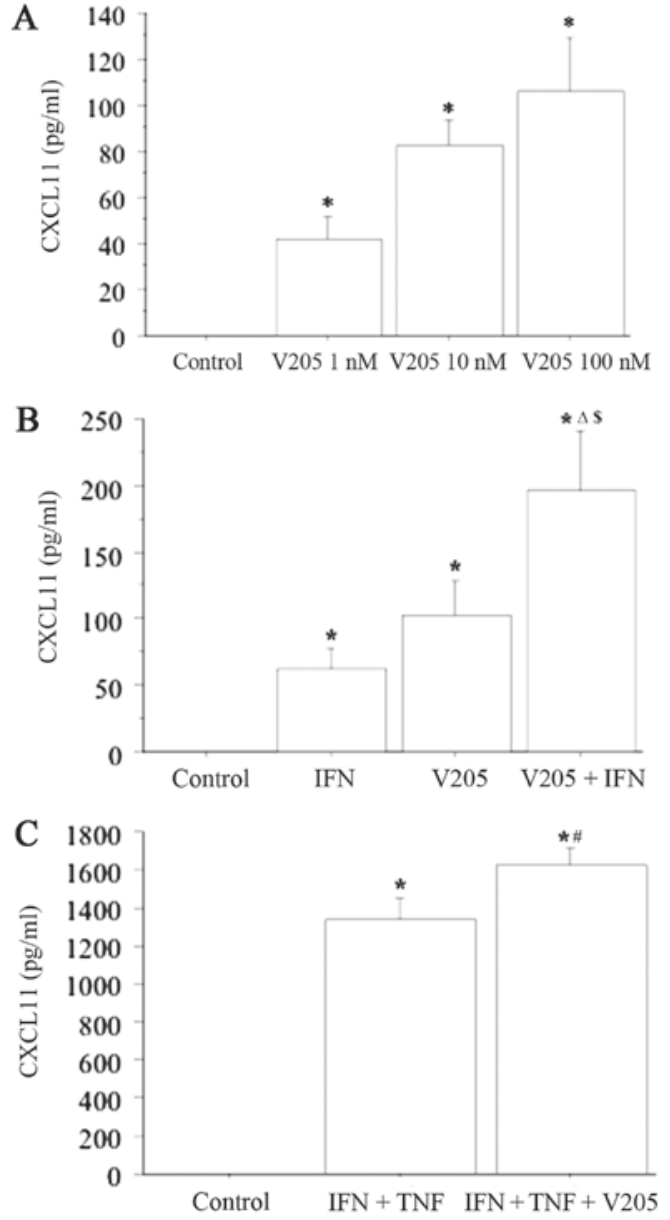

Figure 4. CXCL11 secretion from thyroid follicular cells. (A) CXCL11 release was dose-dependently stimulated from thyrocytes treated with $\mathrm{V}_{2} \mathrm{O}_{5}(1,10$ and $100 \mathrm{nM})$. (B) Following treatment with $\mathrm{V}_{2} \mathrm{O}_{5}(100 \mathrm{nM})$ together with IFN- $\gamma$, CXCL11 release was synergistically increased. (C) CXCL11 release was synergistically increased from thyrocytes treated with $\mathrm{V}_{2} \mathrm{O}_{5}(100 \mathrm{nM})$ together with IFN- $\gamma$ and TNF- $\alpha$. ${ }^{*} \mathrm{P}<0.05$ vs. control; ${ }^{\Delta} \mathrm{P}<0.05$ vs. IFN; ${ }^{\$} \mathrm{P}<0.05$ vs. $\mathrm{V}_{2} \mathrm{O}_{5}$; ${ }^{\#} \mathrm{P}<0.05$ vs. IFN+TNF. CXCL11, chemokine (C-X-C motif) ligand 11; TNF, tumor necrosis factor; $\mathrm{V}_{2} \mathrm{O}_{5}$, vanadium pentoxide; IFN, interferon.

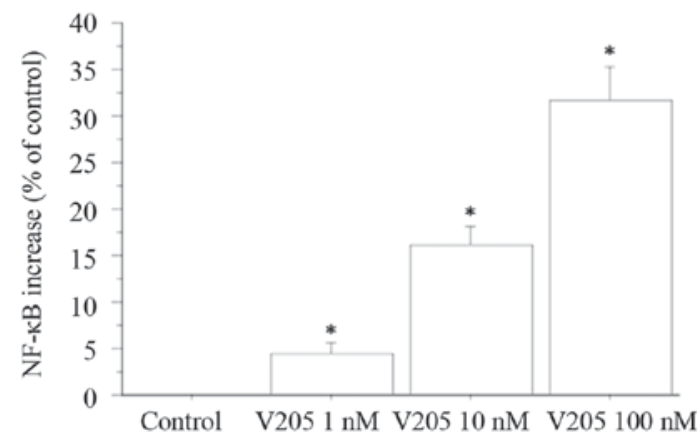

Figure 5. NF- $\kappa \mathrm{B}$ release from thyroid follicular cells following $\mathrm{V}_{2} \mathrm{O}_{5}$ treatment. NF- $\kappa$ B release was dose-dependently stimulated by treating thyrocytes with $\mathrm{V}_{2} \mathrm{O}_{5}(1,10$ and $100 \mathrm{nM})$, with respect to control treatment. ${ }^{*} \mathrm{P}<0.05$ vs. Control. $\mathrm{V}_{2} \mathrm{O}_{5}$, vanadium pentoxide; $\mathrm{NF}$, nuclear factor.

with other studies reporting an association between CXCL8 or CXCL11 secretion and the NF- $\mathrm{B}$ pathway (28-31).

The results of our study agree with those of other research on different cell types. $\mathrm{V}_{2} \mathrm{O}_{5}$ exposure is a cause of occupational bronchitis, and a previous study evaluated gene expression profiles in human lung fibroblasts (in cultures) after in vitro exposure to $\mathrm{V}_{2} \mathrm{O}_{5}$, aiming to identify genes that could have a role in bronchial inflammation, repair, and fibrosis in the pathogenesis of bronchitis. About twelve genes were overexpressed in response to $\mathrm{V}_{2} \mathrm{O}_{5}$ among which were CXCL8 and the IFN-gamma-dependent chemokines CXCL9 and CXCL10 (14).

Interestingly, vanadium was able to increase chemokine secretion over a dose range from 1 to $100 \mathrm{nM}$. It has been reported that normal blood levels of vanadium range from 0.45 to $18.4 \mathrm{nM}$, and that $100 \mathrm{nM}$ is a dose that may mimic an abnormally high exposure (32).

Many studies conducted on mice have investigated the mechanism through which $\mathrm{V}_{2} \mathrm{O}_{5}$ induces lung cancer. In vivo and in vitro research suggests that lung cancers are induced by secondary mechanisms, rather than direct genotoxic pathways (33). Therefore, it may also be hypothesized that the induction of an inflammatory reaction in the thyroid may predispose for the development of thyroid cancer, as recently seen for autoimmune thyroiditis.

In conclusion, our study shows that $\mathrm{V}_{2} \mathrm{O}_{5}$ is able to induce the secretion of the chemokines CXCL8 and CXCL11 in the thyroid. Interestingly, $\mathrm{V}_{2} \mathrm{O}_{5}$ synergistically increased the effect of IFN-gamma on CXCL11 secretion. Moreover, $\mathrm{V}_{2} \mathrm{O}_{5}$ synergistically increased the effect of TNF-alpha on CXCL8 secretion, abolishing the inhibitory effect of IFN-gamma. On the whole, these findings indicate that induction of CXCL8 and CXCL11 secretion may lead to the induction and perpetuation of an inflammatory reaction in the thyroid. Further studies are now necessary to investigate the mechanism of action at the basis of this induction, and to evaluate thyroid function and nodule development in occupationally and environmentally exposed subjects, in order to clarify the relevance of these results in vivo.

\section{Acknowledgements}

Not applicable.

\section{Funding}

No funding was received.

\section{Availability of data and materials}

All data generated or analyzed during this study are included in this published article.

\section{Authors' contributions}

PF, RF, AC, AA and SMF made substantial contributions to the conception and design of the study, and to the acquisition of data. GE, FR, AP, GF and SB analysed the data. PF, AA and SMF drafted the manuscript, and AA revised it critically for important intellectual content. All authors read and approved the final manuscript.

\section{Ethics approval and consent to participate}

Written informed consent for the present study was obtained from all patients, and the study was approved by the local Ethical Committee of the University of Pisa (Pisa, Italy). 


\section{Consent for publication}

Written informed consent was obtained from all participating patients.

\section{Competing interests}

The authors declare that they have no competing interests.

\section{References}

1. Occupational safety and health administration: Occupational safety and health guidelines for vanadium pentoxide. https:// www.osha.gov/SLTC/healthguidelines/vanadiumpentoxidedust/ recognition.html. Accessed January 29, 2009.

2. Sax NI: Dangerous properties of industrial materials. 6th edtion Van Nostrand Reinhold Company, New York, pp2717-2720, 1984

3. Ress NB, Chou BJ, Renne RA, Dill JA, Miller RA, Roycroft JH Hailey JR, Haseman JK and Bucher JR: Carcinogenicity of inhaled vanadium pentoxide in $\mathrm{F} 344 / \mathrm{N}$ rats and $\mathrm{B} 6 \mathrm{C} 3 \mathrm{~F} 1$ mice. Toxicol Sci 74: 287-296, 2003.

4. Wörle-Knirsch JM, Kern K, Schleh C, Adelhelm C, Feldmann C and Krug HF: Nanoparticulate vanadium oxide potentiated vanadium toxicity in human lung cells. Environ Sci Technol 41: 331-336, 2007.

5. Scibior A, Zaporowska H and Ostrowski J: Selected haematological and biochemical parameters of blood in rats after subchronic administration of vanadium and/or magnesium in drinking water. Arch Environ Contam Toxicol 51: 287-295, 2006

6. González-Villalva A, Fortoul TI, Avila-Costa MR, Piñón-Zarate G, Rodriguez-Laraa V, Martínez-Levy G, Rojas-Lemus M, Bizarro-Nevarez P, Díaz-Bech P, Mussali-Galante P and Colin-Barenque L: Thrombocytosis induced in mice after subacute and subchronic V2O5 inhalation. Toxicol Ind Health 22: 113-116, 2006.

7. Kobayashi K, Himeno S, Satoh M, Kuroda J, Shibata N, Seko Y and Hasegawa T: Pentavalent vanadium induces hepatic metallothionein through interleukin-6-dependent and -independent mechanisms. Toxicology 228: 162-170, 2006.

8. Soazo M and Garcia GB: Vanadium exposure through lactation produces behavioral alterations and CNS myelin deficit in neonatal rats. Neurotoxicol Teratol 29: 503-510, 2007.

9. Barceloux DG: Vanadium. J Toxicol Clin Toxicol 37: 265-278, 1999.

10. Malandrino P, Russo M, Ronchi A, Minoia C, Cataldo D, Regalbuto C, Giordano C, Attard M, Squatrito S, Trimarchi F and Vigneri R: Increased thyroid cancer incidence in a basaltic volcanic area is associated with non-anthropogenic pollution and biocontamination. Endocrine 53: 471-479, 2016.

11. Ferrari SM,Fallahi P,Antonelli A and Benvenga S: Environmental issues in thyroid diseases. Front Endocrinol (Lausanne) 8: 50, 2017.

12. Rotondi M, Coperchini F, Pignatti P, Sideri R, Groppelli G, Leporati P, La Manna L, Magri F, Mariotti S and Chiovato L: Interferon- $\gamma$ and tumor necrosis factor- $\alpha$ sustain secretion of specific CXC chemokines in human thyrocytes: A first step toward a differentiation between autoimmune and tumor-related inflammation? J Clin Endocrinol Metab 98: 308-313, 2013.

13. Antao-Menezes A, Turpin EA, Bost PC, Ryman-Rasmussen JP and Bonner JC: STAT-1 signaling in human lung fibroblasts is induced by vanadium pentoxide through an IFN-beta autocrine loop. J Immunol 180: 4200-4207, 2008.

14. Ingram JL, Antao-Menezes A, Turpin EA, Wallace DG, Mangum JB, Pluta LJ, Thomas RS and Bonner JC: Genomic analysis of human lung fibroblasts exposed to vanadium pentoxide to identify candidate genes for occupational bronchitis. Respir Res 8: 34, 2007.

15. Garcià-Lòpez MA, Sancho D, Sànchez-Madrid F and Marazuela M: Thyrocytes from autoimmune thyroid disorders produce the chemokines IP-10 and Mig and attract CXCR3+ lymphocytes. J Clin Endocrinol Metab 86: 5008-5016, 2001.

16. Antonelli A, Ferri C, Fallahi P, Ferrari SM, Frascerra S, Sebastiani M, Franzoni F, Galetta F and Ferrannini E: High values of CXCL10 serum levels in patients with hepatitis C associated mixed cryoglobulinemia in presence or absence of autoimmune thyroiditis. Cytokine 42: 137-143, 2008.
17. Antonelli A, Ferrari SM, Fallahi P, Frascerra S, Santini E, Franceschini SS and Ferrannini E: Monokine induced by interferon gamma (IFNgamma) (CXCL9) and IFNgamma inducible T-cell alpha-chemoattractant (CXCL11) involvement in Graves' disease and ophthalmopathy: Modulation by peroxisome proliferator-activated receptor-gamma agonists. J Clin Endocrinol Metab 94: 1803-1809, 2009.

18. Antonelli A, Rotondi M, Fallahi P, Romagnani P, Ferrari SM, Buonamano A, Ferrannini E and Serio M: High levels of circulating CXC chemokine ligand 10 are associated with chronic autoimmune thyroiditis and hypothyroidism. J Clin Endocrinol Metab 89: 5496-5499, 2004.

19. Antonelli A, Ferrari SM, Frascerra S, Pupilli C, Mancusi C, Metelli MR, Orlando C, Ferrannini E and Fallahi P: CXCL9 and CXCL11 chemokines modulation by peroxisome proliferator-activated receptor-alpha agonists secretion in Graves' and normal thyrocytes. J Clin Endocrinol Metab 95: E413-E420, 2010.

20. Quent VM, Loessner D, Friis T, Reichert JC and Hutmacher DW: Discrepancies between metabolic activity and DNA content as tool to assess cell proliferation in cancer research. J Cell Mol Med 14: 1003-1013, 2010.

21. Kemp EH, Metcalfe RA, Smith KA, Woodroofe MN, Watson PF and Weetman AP: Detection and localization of chemokine gene expression in autoimmune thyroid disease. Clin Endocrinol (Oxf) 59: 207-213, 2003.

22. Antonelli A, Bocci G, La Motta C, Ferrari SM, Fallahi P, Fioravanti A, Sartini S, Minuto M, Piaggi S, Corti A, et al: Novel pyrazolopyrimidine derivatives as tyrosine kinase inhibitors with antitumoral activity in vitro and in vivo in papillary dedifferentiated thyroid cancer. J Clin Endocrinol Metab 96: E288-E296, 2011.

23. Antonelli A, Ferrari SM, Fallahi P, Berti P, Materazzi G, Barani L, Marchetti I, Ferrannini E and Miccoli P: Primary cell cultures from anaplastic thyroid cancer obtained by fine-needle aspiration used for chemosensitivity tests. Clin Endocrinol (Oxf) 69: 148-152, 2008.

24. Antonelli A, Ferrari SM, Corrado A, Ferrannini E and Fallahi P: CXCR3, CXCL10 and type 1 diabetes. Cytokine Growth Factor Rev 25: 57-65, 2014

25. Antonelli A, Ferrari SM, Giuggioli D, Ferrannini E, Ferri C and Fallahi P: Chemokine (C-X-C motif) ligand (CXCL)10 in autoimmune diseases. Autoimmun Rev 13: 272-280, 2014.

26. Fallahi P, Ferrari SM, Ruffilli I, Elia G, Biricotti M, Vita R, Benvenga $S$ and Antonelli A: The association of other autoimmune diseases in patients with autoimmune thyroiditis: Review of the literature and report of a large series of patients. Autoimmun Rev 15: 1125-1128, 2016.

27. Antonelli A, Fallahi P, Delle Sedie A, Ferrari SM, Maccheroni M, Bombardieri S, Riente L and Ferrannini E: High values of Th1 (CXCL10) and Th2 (CCL2) chemokines in patients with psoriatic arthtritis. Clin Exp Rheumatol 27: 22-27, 2009.

28. Jayaprakash K, Demirel I, Gunaltay S, Khalaf H and Bengtsson T: $\mathrm{PKC}, \mathrm{ERK} / \mathrm{p} 38 \mathrm{MAP}$ kinases and $\mathrm{NF}-\kappa \mathrm{B}$ targeted signalling play a role in the expression and release of IL-1 $\beta$ and CXCL8 in Porphyromonas gingivalis-infected THP1 cells. APMIS 125: 623-633, 2017.

29. Shen T, Yang Z, Cheng X, Xiao Y, Yu K, Cai X, Xia C and Li Y: CXCL8 induces epithelial-mesenchymal transition in colon cancer cells via the PI3K/Akt/NF- $\kappa \mathrm{B}$ signaling pathway. Oncol Rep 37: 2095-2100, 2017.

30. Crescioli C, Sottili M, Bonini P, Cosmi L, Chiarugi P, Romagnani P, Vannelli GB, Colletti M, Isidori AM, Serio M, et al: Inflammatory response in human skeletal muscle cells: CXCL10 as a potential therapeutic target. Eur J Cell Biol 91: 139-149, 2012.

31. Antonelli A, Ferrari SM, Fallahi P, Frascerra S, Piaggi S, Gelmini S, Lupi C, Minuto M, Berti P, Benvenga S, et al: Dysregulation of secretion of CXC alpha-chemokine CXCL10 in papillary thyroid cancer: Modulation by peroxisome proliferator-activated receptor-gamma agonists. Endocr Relat Cancer 16: 1299-1311, 2009.

32. Sabbioni E, Kuèera J, Pietra R and Vesterberg O: A critical review on normal concentrations of vanadium in human blood, serum, and urine. Sci Total Environ 188: 49-58, 1996.

33. Assem FL and Levy LS: A review of current toxicological concerns on vanadium pentoxide and other vanadium compounds: Gaps in knowledge and directions for future research. J Toxicol Environ Health B Crit Rev 12: 289-306, 2009. 